\title{
PENGUJIAN ADAPTASI BEBERAPA KLON KARET PADA MASA TANAMAN BELUM MENGHASILKAN
}

\author{
Adaptation Test of Several Rubber Clones in Immature Period \\ SAYURANDI, Irwan SUHENDRY, dan Syarifah Aini PASARIBU \\ Balai Penelitian Sungei Putih, Pusat Penelitian Karet \\ PO BOX 1415, Medan 20001 \\ Email : sayurandi_sp@yahoo.com
}

Diterima : 8 Oktober 2013/ Direvisi : 24 Desember 2013 / Disetujui : 4 Maret 2014

\begin{abstract}
The purpose of this study was to evaluate the performance of several rubber clones in adaptation test in immature period. A total of nine rubber clones, namely IRR 5, IRR 104, IRR 112, IRR 118, IRR 119, IRR 230, PB 217, RRIM 921, RRII 105 and control clone PB 260 which were evaluated in this research. Adaptation test performed on two locations which have different agroecosystems, viz. Gunung Tua which is located in North Padang Lawas district which has a dry agroclimate location and Batang Toru which is located in South Tapanuli district which has a wet agroclimate location.The adaptation tests were conducted in 2005 and 2007 by using a randomized block design (RBD). Observations were done on girth size over 2, 3 and 4 years, while bark thickness and bark anatomy were observed at 4 years. The attack intensity of Oidium, Colletotrichum, and Corynespora leaf fall diseases at 3 years. The research results showed that clones IRR 104 and IRR 118 had growth vigorous in dry agroclimate, while clones IRR 5, IRR 112, PB 217 and RRIM 921 had vigorous growth in wet agroclimate. Based on bark thickness and bark anatomy characters, showed that clones IRR 5, PB 217, RRII 105, and RRIM 921 had highest bark thickness, while clones IRR 5, IRR 104, IRR 112, IRR 118, and IRR 230 had good bark anatomy character. All clones were classified from moderately resistant to resistant to Oidium, Colletotrichum, and Corynespora leaffall diseases.
\end{abstract}

Keywords: Hevea brasiliensis, rubber clones, adaptation trial, growth, secondary characteristics

\section{Abstrak}

Tujuan dari penelitian ini adalah untuk mengevaluasi kinerja beberapa klon karet pada pengujian adaptasi selama masa tanaman belum menghasilkan. Sebanyak sembilan klon karet yaitu IRR 5, IRR 104, IRR 112, IRR 118, IRR 119, IRR 230, PB 217, RRIM 921, RRII 105 dan klon pembanding PB 260 diuji dalam penelitian ini.
Pengujian adaptasi dilakukan pada dua daerah yang memiliki agroekosistem yang berbeda, yaitu Gunung Tua yang terletak di Kabupaten Padang Lawas Utara memiliki iklim yang lebih kering dan Batang Toru terletak di Kabupaten Tapanuli Selatan memiliki iklim yang lebih basah. Pengujian adaptasi dibangun pada tahun 2005 dan 2007 dengan menggunakan rancangan acak kelompok (RAK). Pengamatan karakter pertumbuhan lilit batang dilakukan pada umur 2, 3 dan 4 tahun, sedangkan karakter tebal kulit dan anatomi kulit diamati pada umur 4 tahun. Intensitas serangan penyakit gugur daun Oidium, Colletotrichum, dan Corynespora diamati pada umur 3 tahun. Hasil pengujian menunjukkan bahwa klon IRR 104 dan IRR 118 memiliki pertumbuhan yang cukup jagur di daerah kering, sedangkan klon IRR 5, IRR 112, PB 217 dan RRIM 921 memiliki pertumbuhan paling jagur pada kondisi iklim lebih basah. Berdasarkan karakter tebal kulit dan anatomi kulit menunjukkan klon IRR 5, PB 217, RRII 105, dan RRIM 921 memiliki karakter tebal kulit paling tinggi, sedangkan klon IRR 5, IRR 104, IRR 112, IRR 118, dan IRR 230 memiliki karakter anatomi kulit yang cukup baik. Semua klon yang diuji tergolong agak resisten hingga resisten terhadap penyakit gugur daun Oidium, Colletotrichum, dan Corynespora.

Kata kunci: Hevea brasiliensis, klon karet, pengujian adaptasi, pertumbuhan, karakteristik sekunder

\section{PENDAHULUAN}

Kegiatan pemuliaan tanaman karet dalam upaya memperoleh klon-klon karet unggul yang lebih produktif terus dilakukan melalui program pemuliaan dan seleksi tanaman. Klon-klon karet unggul anjuran yang ditanam di perkebunan besar/rakyat memiliki produksi karet aktualnya lebih rendah dibandingkan dengan potensi produktivitasnya. Penyebab utama 
rendahnya produksi karet diakibatkan oleh adanya pengaruh faktor lingkungan biologi, agroklimat dan manajemen tanaman (AidiDaslin et al., 2000).

Siklus pemuliaan tanaman karet di Indonesia telah memasuki generasi ke empat (G-IV). Pada generasi tersebut telah diperoleh klon-klon unggul harapan seri IRR dan klon hasil introduksi dengan potensi produktivitas yang lebih tinggi. Dari hasil evaluasi pada tahap pengujian pendahuluan dan plot promosi, klon-klon seri IRR memiliki potensi produktivitas karet sebesar 2000 - $2500 \mathrm{~kg} / \mathrm{ha} / \mathrm{th}$ dan potensi volume kayu sekitar $300 \mathrm{~m}^{3}$ /ha (Suhendry et al., 2001; Woelan et al., 2001).

Sebelum direkomendasikan untuk pertanaman komersial sebagai klon unggul anjuran, klon-klon unggul sebaiknya diuji pada beberapa agroekosistem yang berbeda. Pengujian ini penting dilakukan, karena tidak ada klon karet yang unggul di semua lokasi penanaman (Alwi dan Aidi-Daslin, 1990). Beberapa klon unggul memiliki daya adaptasi luas dan stabil, tetapi banyak juga klon memiliki respon spesifik pada lingkungan tertentu (Fatunla dan Frey, 1974; Simmonds, 1989).

Klon unggul harapan seri IRR yang terseleksi dari uji pendahuluan dan plot promosi memiliki produktivitas tinggi karena didukung oleh kondisi lingkungan pada areal pengujian tersebut. Respon klon kemungkinan berbeda jika dikembangkan pada kondisi lingkungan yang berbeda (AidiDaslin, 2011). Untuk mengetahui kinerja klon pada lingkungan spesifik atau beradaptasi luas, diperlukan suatu pengujian adaptasi pada agroekosistem yang berbeda.

Artikel ini berisikan hasil evaluasi kinerja beberapa klon karet pada tahap pengujian adaptasi selama masa tanaman belum menghasilkan (TBM).

\section{BAHAN DAN METODE}

Plot Pengujian dibangun pada dua lokasi yaitu di Gunung Tua, Kabupaten Padang Lawas Utara yang ditanam pada tahun 2005 dan di Batang Toru, Kabupaten Tapanuli Selatan yang ditanam pada tahun 2008. Sebanyak 9 klon yaitu IRR 5, IRR 104,
IRR 112, IRR 118, IRR 119, IRR 230, PB 217 , RRIM 921, RRII 105 dan klon pembanding PB 260 diuji pada tiap lokasi dengan menggunakan Rancangan Acak Kelompok (RAK). Deskripsi lokasi pengujian adaptasi dari beberapa klon karet disajikan pada Tabel 1.

Parameter pengam at a $\mathrm{n}$ pertumbuhan lilit batang dilakukan pada umur 2, 3, dan 4 tahun. Sedangkan, parameter tebal kulit, jumlah saluran pembuluh lateks dan diameter saluran pembuluh lateks pada masing-masing klon dilakukan pada umur 4 tahun. Intensitas serangan penyakit gugur daun Oidium, Colletotrichum dan Corynespora diamati pada umur 3 tahun dan dihitung berdasarkan rumus yang dikembangkan oleh Pawirosoemardjo (1999). Indeks stabilitas pertumbuhan pada masingmasing klon ditentukan dengan menggunakan rumus yang dikembangkan oleh Steel dan Torrie (1982) yaitu dengan menghitung variasi (keragaman) antar lokasi.

\section{HASIL DAN PEMBAHASAN}

\section{Pertumbuhan Lilit Batang}

Data pertumbuhan lilit batang pada masa TBM disajikan pada Tabel 2 dan 3 . Hasil pengamatan pertumbuhan lilit batang menunjukkan bahwa pada umumnya klon karet yang diuji di Batang Toru memiliki pertumbuhan lebih jagur dibandingkan dengan di Gunung Tua. Rata-rata pertumbuhan lilit batang klon karet di kebun Batang Toru pada umur 2 tahun sebesar 26,0 cm, umur 3 tahun sebesar 37,0 $\mathrm{cm}$, dan umur 4 tahun sebesar 45,2 cm dengan koefisien keragaman (KK) berkisar 1,2 - 6,8\%. Sedangkan di Gunung Tua memperlihatkan pertumbuhan yang lebih lambat dengan pertumbuhan lilit batang pada umur 2 tahun sebesar $16,2 \mathrm{~cm}$, umur 3 tahun sebesar 29,5 cm, dan umur 4 tahun sebesar 39,7 cm dengan KK berkisar 2,9 $11,8 \%$. Terlambatnya pertumbuhan tanaman di Gunung Tua diduga diakibatkan oleh curah hujan yang cukup rendah. Wijaya et al (2001) menyatakan pertumbuhan tanaman dapat terhambat akibat cekaman kekeringan. Chandrasekar et al (1994) juga menyatakan bahwa respon klon terhadap cekaman kekeringan berbeda. 
Tabel 1. Deskripsi lokasi pengujian adaptasi

Table 1. Description of adaptation test locations

\begin{tabular}{|c|c|c|c|}
\hline \multirow[t]{2}{*}{ No. } & \multirow{2}{*}{$\begin{array}{c}\text { Keterangan } \\
\text { Remarks }\end{array}$} & \multicolumn{2}{|c|}{$\begin{array}{l}\text { Lokasi pengujian } \\
\text { Trial locations }\end{array}$} \\
\hline & & Gunung Tua & Batang Toru \\
\hline \multirow[t]{2}{*}{1.} & Tahun tanam & 2005 & 2008 \\
\hline & Planting year & & \\
\hline \multirow[t]{2}{*}{2.} & Klon yang diuji & Seri IRR dan klon introduksi & Seri IRR dan klon introduksi \\
\hline & Tested clones & (IRR series and introduction clones) & (IRR series and introduction clones) \\
\hline \multirow[t]{2}{*}{3.} & Rancangan percobaan & Rancangan Acak Kelompok & Rancangan Acak Kelompok \\
\hline & Experimental design & (Randomized Block Design) & (Randomized Block Design) \\
\hline \multirow[t]{2}{*}{4.} & Jumlah ulangan & 2 ulangan (replications) & 2 ulangan (replications) \\
\hline & Number of replications & & \\
\hline \multirow[t]{2}{*}{5.} & Jarak tanam & $5 \times 4 \mathrm{~m}$ & $5 \times 4 \mathrm{~m}$ \\
\hline & Planting distance & & \\
\hline \multirow[t]{2}{*}{6.} & Luas plot & $0,25-0,5$ ha & $0,25-0,5$ ha \\
\hline & Plot size & & \\
\hline \multirow[t]{2}{*}{7.} & Jumlah tanaman & $150-250$ pohon (trees) & $100-250$ pohon (trees) \\
\hline & Number of plants & & \\
\hline \multirow[t]{2}{*}{8.} & Luas areal & 15 ha & 12 ha \\
\hline & Hectarage & & \\
\hline \multirow[t]{2}{*}{9.} & Topografi & Datar (flat) & Datar dan berbukit (flat and hilly) \\
\hline & Topography & & \\
\hline \multirow[t]{2}{*}{10.} & Tinggi tempat & $150 \mathrm{~m}$ dpl (above see level) & $300 \mathrm{~m}$ dpl (above see level) \\
\hline & Elevation & & \\
\hline \multirow[t]{2}{*}{11.} & Jenis tanah & Ultisol & Ultisol \\
\hline & Soil types & & \\
\hline \multirow[t]{2}{*}{12.} & Rata-rata curah hujan & $1450 \mathrm{~mm} /$ th $(\mathrm{mm} / \mathrm{yr})$ & $3100 \mathrm{~mm} /$ th $(\mathrm{mm} / \mathrm{yr})$ \\
\hline & Average rain fall & & \\
\hline \multirow[t]{2}{*}{13.} & Jumlah hari hujan & $60-90$ hari/th (days/yr) & 125-165 hari/th (days/yr) \\
\hline & Rainday number & & \\
\hline \multirow[t]{2}{*}{14.} & Jumlah bulan kering & 4-5 bulan/th (months/yr) & 2-3 bulan/th (months/yr) \\
\hline & Number of dry month & & \\
\hline
\end{tabular}

Tabel 2 menunjukkan bahwa klon yang memiliki pertumbuhan cukup jagur pada umur 4 tahun di Gunung Tua adalah IRR 104 (41,2 cm) dan IRR $118(40,1 \mathrm{~cm})$ dengan laju pertambahan lilit batang masing-masing sebesar $10,1 \mathrm{~cm} /$ th dan 10,7 $\mathrm{cm} /$ th. Pertumbuhan klon-klon tersebut sebesar $101,0 \%$ dan $100,2 \%$ terhadap klon pembanding PB 260 (40,8 cm). Klon yang memiliki pertumbuhan paling lambat yaitu RRII 105 (38,4 cm) dan RRIM $921(37,7 \mathrm{~cm})$ atau 94, 1\% dan 92,4\% terhadap klon PB 260. Berdasarkan rata-rata pertumbuhan lilit batang klon, pada umumnya klon karet yang diuji diperkirakan dapat disadap pada umur 4,5-5,5 tahun.
Tabel 3 menunjukkan bahwa di kebun Batang Toru, sebagian klon memiliki pertumbuhan lilit batang cukup jagur, pada umur 4 tahun ukuran lilit batang $\geq 45 \mathrm{~cm}$. Siagian et al (2005) menyatakan pertumbuhan lilit batang $\geq 45 \mathrm{~cm}$ pada TBM 4 tergolong jagur. Klon yang tergolong cukup jagur adalah IRR 5 (45,8 cm), IRR 112 (45,3 cm), IRR 119 (45,2 cm), IRR 230 (45,7 cm) dengan laju pertambahan lilit batang berkisar antara 9,6-11,6 cm/th. Klon yang lainnya memiliki pertumbuhan yang masih tergolong cukup baik dengan ukuran lilit batang $\geq 44 \mathrm{~cm} /$ th. Menurut Aidi-Daslin (2005), klon karet yang tergolong jagur memiliki pertumbuhan awal cepat selama 
Tabel 2. Pertumbuhan lilit batang beberapa klon di lokasi pengujian Gunung Tua Table 2. Girth growth of several rubber clones at Gunung Tua test location

\begin{tabular}{|c|c|c|c|c|}
\hline \multirow{2}{*}{$\begin{array}{l}\text { Klon } \\
\text { Clones }\end{array}$} & \multicolumn{3}{|c|}{$\begin{array}{c}\text { Lilit batang }(\mathrm{cm}) \text {, pada umur (tahun) } \\
\text { Girth }(\mathrm{cm}) \text {, at age (years) }\end{array}$} & \multirow{2}{*}{$\begin{array}{c}\text { Pertambahan lilit } \\
\text { batang } \\
\text { (cm/tahun) } \\
\text { Girth increment } \\
\text { (cm/year) }\end{array}$} \\
\hline & 2 & 3 & 4 & \\
\hline IRR 5 & 15,8 & 32,6 & $38,0(93,1 \%)$ & $11,0(107,8 \%)$ \\
\hline IRR 104 & 20,2 & 33,3 & 41,2 (101,0\%) & $10,1(99,0 \%)$ \\
\hline IRR 112 & 18,1 & 30,0 & $38,4(94,7 \%)$ & $10,8(105,9 \%)$ \\
\hline IRR 118 & 15,1 & 32,1 & 40,9 (100,2\%) & 10,7 (104,9\%) \\
\hline IRR 119 & 16,2 & 29,5 & $39,0(95,6 \%)$ & $10,2(100,0 \%)$ \\
\hline IRR 230 & 13,8 & 29,3 & $39,8(97,5 \%)$ & $10,4(101,9 \%)$ \\
\hline PB 217 & 17,2 & 29,1 & $39,9(97,8 \%)$ & $10,2(100,0 \%)$ \\
\hline RRII 105 & 15,3 & 25,0 & $38,4(94,1 \%)$ & $10,4(102,0 \%)$ \\
\hline RRIM 921 & 14,1 & 26,3 & 37,7 (92,4\%) & $10,2(100,0 \%)$ \\
\hline PB 260 & 15,9 & 27,9 & $40,8(100,0 \%)$ & $10,2(100,0 \%)$ \\
\hline $\begin{array}{l}\text { Rata-rata } \\
\text { Average }\end{array}$ & 16,2 & 29,5 & 39,7 & 10,5 \\
\hline $\begin{array}{l}\text { Minimum } \\
\text { Minimum }\end{array}$ & 13,8 & 25,0 & 37,7 & 10,1 \\
\hline $\begin{array}{l}\text { Maksimum } \\
\text { Maximum }\end{array}$ & 20,2 & 33,3 & 41,2 & 11,4 \\
\hline $\begin{array}{l}\text { Simpangan baku } \\
\text { Standard deviation }\end{array}$ & 1,9 & 2,7 & 1,2 & 0,4 \\
\hline $\begin{array}{l}\text { Koef. keragaman }(\%) \\
\text { Coeff. of variation }\end{array}$ & 11,8 & 9,1 & 2,9 & 4,1 \\
\hline
\end{tabular}

Tabel 3. Pertumbuhan lilit batang beberapa klon di lokasi pengujian Batang Toru Table 3. Girth growth of several rubber clones at Batang Toru test location

\begin{tabular}{|c|c|c|c|c|}
\hline \multirow{2}{*}{$\begin{array}{l}\text { Klon } \\
\text { Clones }\end{array}$} & \multicolumn{3}{|c|}{$\begin{array}{c}\text { Lilit batang }(\mathrm{cm}) \text {, pada umur (tahun) } \\
\text { Girth }(\mathrm{cm}) \text {, at age (years) }\end{array}$} & \multirow{2}{*}{$\begin{array}{l}\text { Pertambahan } \\
\text { lilit batang } \\
\text { (cm/tahun) } \\
\text { Girth incremen } \\
\text { (cm/year) }\end{array}$} \\
\hline & 2 & 3 & 4 & \\
\hline IRR 5 & 26,9 & 36,1 & $45,8 \quad(101,3 \%)$ & $11,6(116,0 \%)$ \\
\hline IRR 104 & 22,4 & 38,4 & $44,0 \quad(97,3 \%)$ & $10,5(105,0 \%)$ \\
\hline IRR 112 & 25,9 & 37,4 & $45,3(100,2 \%)$ & $11,3(113,0 \%)$ \\
\hline IRR 118 & 26,4 & 38,1 & $44,1 \quad(97,6 \%)$ & $10,5(105,0 \%)$ \\
\hline IRR 119 & 28,0 & 36,7 & $45,2 \quad(100 \%)$ & $10,7(107,0 \%)$ \\
\hline IRR 230 & 28,3 & 38,2 & 45,7 (101,1\%) & $10,8(108,0 \%)$ \\
\hline PB 217 & 26,9 & 34,4 & $45,3(100,2 \%)$ & $10,0(100,0 \%)$ \\
\hline RRII 105 & 24,5 & 36,0 & $44,5(98,5 \%)$ & $10,8(108,0 \%)$ \\
\hline RRIM 921 & 25,4 & 37,0 & $45,8(101,3 \%)$ & $9,6(96,0 \%)$ \\
\hline PB 260 & 27,6 & 38,1 & $45,2(100,0 \%)$ & $10,0(100,0 \%)$ \\
\hline $\begin{array}{l}\text { Rata-rata } \\
\text { Average }\end{array}$ & 26,2 & 37,0 & 45,2 & 10,6 \\
\hline $\begin{array}{l}\text { Minimum } \\
\text { Minimum }\end{array}$ & 22,4 & 34,4 & 44,1 & 9,6 \\
\hline $\begin{array}{l}\text { Maksimum } \\
\text { Maximum }\end{array}$ & 28,3 & 38,4 & 45,8 & 11,6 \\
\hline $\begin{array}{l}\text { Simpangan baku } \\
\text { Standard deviation }\end{array}$ & 1,8 & 1,3 & 0,6 & 0,6 \\
\hline $\begin{array}{l}\text { Koef. keragaman }(\%) \\
\text { Coeff. of variation }\end{array}$ & 6,8 & 3,4 & 1,2 & 5,7 \\
\hline
\end{tabular}


masa TBM dengan rata-rata pertambahan lilit batang $\geq 11 \mathrm{~cm} /$ th. Berdasarkan ratarata pertumbuhan lilit batang masingmasing klon, maka klon tersebut sudah dapat disadap pada umur 4 tahun.

\section{Stabilitas Pertumbuhan Tanaman}

Klon yang tergolong baik adalah klon yang memiliki adaptasi luas dan stabil pada setiap lingkungan tumbuh tanaman (Fatunla dan Frey, 1974; Mydin et al., 2012). Perhitungan nilai indeks stabilitas suatu tanaman sangat penting dilakukan, untuk memperoleh klon yang memiliki pertumbuhan stabil ataupun tumbuh baik pada lokasi spesifik (Eberhart dan Russell, 1966; Nor dan Cady, 1979). Klon karet yang memiliki tingkat stabilitas baik ditandai dengan nilai indeks stabilitas rendah. Sebaliknya klon yang memiliki nilai indeks stabilitas tinggi adalah klon dengan tingkat stabilitas rendah. Indeks stabilitas pertumbuhan lilit batang pada beberapa klon karet disajikan pada Tabel 4.

Tabel 4 menunjukkan bahwa nilai indeks stabilitas pertumbuhan klon yang diuji berkisar antara $0,23-0,57$. Klon IRR 104 dan IRR 118 memiliki nilai indeks stabilitas pertumbuhan paling rendah dibandingkan dengan klon lainnya dengan nilai masing-masing 0,27 dan 0,23. Nilai indeks stabilitas yang rendah menunjukkan bahwa kedua klon memiliki pertumbuhan tanaman relatif stabil dibandingkan dengan klon yang lain. Rata-rata ukuran lilit batang klon tersebut adalah $42,6 \mathrm{~cm}$ dan $42,5 \mathrm{~cm}$. Walaupun kedua klon tersebut memiliki tingkat stabilitas yang paling baik pada dua lokasi pengujian, tetapi memiliki pertumbuhan kurang jagur di Batang Toru.

Klon IRR 5, IRR 112, dan RRIM 921 memiliki pertumbuhan kurang stabil dengan indeks stabilitas masing-masing 0,48; 0,49 dan 0,57. Eberhart dan Rusell (1966) menyatakan bahwa suatu genotipe tergolong stabil jika memiliki nilai indeks stabilitas rendah demikian pula sebaliknya. Klon PB 217 dan PB 260 memiliki pertumbuhan yang cukup baik pada daerah kering di Gunung Tua. Di Batang Toru respon klon terhadap curah hujan tinggi cukup baik. Klon IRR 5, IRR 112, IRR 230, PB 217 dan RRIM 921 memiliki pertumbuhan paling jagur.

Tabel 4 menunjukkan bahwa pertumbuhan tanaman di Gunung Tua terlihat lebih tertekan dibandingkan di Batang Toru. Hal ini mengindikasikan bahwa pengaruh lokasi sangat signifikan terhadap pertumbuhan tanaman. Rendahnya curah hujan di daerah Gunung Tua merupakan salah satu penyebab pertumbuhan tanaman lebih lambat dibandingkan dengan daerah Batang Toru. Menurut Karyudi (2001) bahwa respon pertumbuhan klon karet lebih terhambat

Tabel 4. Ukuran lilit batang dan indeks stabilitas beberapa klon karet

Table 4. Girth size and stability index of several rubber clones

\begin{tabular}{lcccc}
\hline \multirow{2}{*}{ Klon } & \multicolumn{3}{c}{$\begin{array}{c}\text { Lilit batang pada umur 4 tahun } \\
\text { Girth at 4 years } \\
\text { Clones }\end{array}$} & \multicolumn{3}{c}{$\begin{array}{c}\text { Lokasi } \\
\text { Locations }\end{array}$} & $\begin{array}{c}\text { Indeks } \\
\text { stabilitas } \\
\text { Stability } \\
\text { index }\end{array}$ \\
\cline { 2 - 3 } & \multicolumn{3}{c}{$\begin{array}{c}\text { Rata-rata } \\
\text { Average }\end{array}$} & \\
\cline { 2 - 3 } IRR 5 & 38,0 & 45,8 & 42,4 & 0,48 \\
IRR 104 & 41,2 & 44,0 & 42,6 & 0,27 \\
IRR 112 & 38,4 & 45,3 & 41,9 & 0,49 \\
IRR 118 & 40,9 & 44,1 & 42,5 & 0,23 \\
IRR 119 & 39,0 & 45,2 & 42,1 & 0,44 \\
IRR 230 & 39,8 & 45,7 & 42,8 & 0,42 \\
PB 217 & 39,9 & 45,3 & 42,6 & 0,38 \\
RRII 105 & 38,4 & 44,5 & 41,5 & 0,43 \\
RRIM 921 & 37,7 & 45,8 & 41,8 & 0,57 \\
PB 260 & 40,8 & 45,2 & 43,0 & 0,31 \\
\hline Rata-rata & 39,7 & 45,1 & 42,4 & \\
Average & 39,7 & &
\end{tabular}


pada daerah kering. Aidi-Daslin et al. ( 2011) juga menyatakan bahwa pertumbuhan klon karet unggul pada umumnya memiliki respon le bih baik pad a daerah/agroekosistem dengan kondisi curah hujan sedang sampai tinggi, namun memiliki bulan kering sekitar $2-3$ bulan pada setiap tahunnya. Dengan demikian, klon karet yang diuji pada umumnya memiliki adaptasi baik pada daerah basah dibandingkan dengan daerah kering.

\section{Tebal Kulit dan Anatomi Kulit}

Ukuran tebal kulit dan anatomi kulit merupakan parameter yang penting dalam melakukan seleksi klon karet unggul harapan. Kedua parameter tersebut memiliki korelasi yang cukup kuat terhadap produksi karet (Novalina, 2009; Goncalves et al., 2005). Data rata-rata ukuran tebal kulit, jumlah saluran dan diameter saluran pembuluh lateks disajikan pada Tabel 5 .
Tabel 5 menunjukkan bahwa ratarata tebal kulit dari klon karet yang diuji berkisar antara 6,0 - 6,9 mm dengan $\mathrm{KK}$ sebesar $4,06 \%$. Klon yang memiliki tebal kulit paling tinggi berturut-turut IRR 5, PB 217, RRII 105, dan RRIM 921, sedangkan yang terendah IRR 118 dan IRR 119. Ratarata jumlah saluran pembuluh lateks dari klon yang diuji berkisar antara 5,75 - 8,25 pembuluh dengan KK sebesar 10,34\%.

Klon yang memiliki jumlah saluran pembuluh lateks tertinggi yaitu IRR 5, IRR 104, IRR 230 dan PB 260, sedangkan yang terrendah IRR 119 dan RRIM 921. Sedangkan, pada parameter diameter saluran pembuluh lateks memiliki variasi yang cukup rendah dengan KK sebesar $4,17 \%$. Rata-rata ukuran diameter pembuluh lateks pada klon yang diuji sebesar 23,96 $\mathrm{m} \mu$ dengan kisaran antara 22,70 - 25,70 $\mathrm{m} \mu$. Klon yang memiliki ukuran diameter pembuluh lateks tertinggi

Tabel 5. Tebal kulit dan anatomi kulit beberapa klon karet pada umur 4 tahun Table 5. Bark thickness and latex vessel of several rubber clones at 4 years

\begin{tabular}{lccc}
\hline \multirow{2}{*}{$\begin{array}{c}\text { Klon } \\
\text { Clones }\end{array}$} & $\begin{array}{c}\text { Tebal kulit } \\
\text { Bark thickness } \\
(\mathrm{cm})\end{array}$ & $\begin{array}{c}\text { Anatomi kulit } \\
\text { Bark anatomy }\end{array}$ \\
\cline { 3 - 4 } & & $\begin{array}{c}\text { Jumlah saluran } \\
\text { pembuluh lateks } \\
\text { Number of latex } \\
\text { vessel rings }\end{array}$ & $\begin{array}{c}\text { Diameter saluran } \\
\text { pembuluh lateks } \\
\text { Diameter of latex } \\
\text { vessel rings } \\
(\mathrm{m} \mu)\end{array}$ \\
\hline IRR 5 & 6,90 & 7,25 & 22,70 \\
IRR 104 & 6,35 & 8,25 & 24,70 \\
IRR 112 & 6,25 & 7,00 & 25,70 \\
IRR 118 & 6,15 & 7,00 & 24,00 \\
IRR 119 & 6,00 & 5,75 & 22,70 \\
IRR 230 & 6,35 & 7,25 & 23,70 \\
PB 217 & 6,65 & 6,75 & 24,20 \\
RRII 105 & 6,60 & 6,50 & 24,70 \\
RRIM 921 & 6,50 & 6,25 & 22,80 \\
PB 260 & 6,45 & 7,75 & 24,40 \\
\hline Rata-rata & 6,42 & 6,98 & 23,96 \\
Avarage & & & 22,70 \\
Minimum & 6,00 & 5,75 & 25,70 \\
Minimum & & & 1,00 \\
Maksimum & 6,90 & 8,25 & 4,17 \\
Maximum & & & \\
Simpangan baku & 0,26 & 0,72 & \\
Standard deviation & & 10,34 & \\
Koef. Keragaman (\%) & 4,06 & & \\
Coeff. of Variation & & &
\end{tabular}


yaitu IRR 104, IRR 112, IRR 118, PB 260 dan RRII 105, sedangkan yang terendah IRR 5 dan IRR 119.

\section{Ketahanan Penyakit}

Ketahanan klon terhadap penyakit gugur daun merupakan parameter yang sangat penting terutama terhadap penyakit daun Oidium, Colletotrichum, dan Corynespora. Penyakit ini memiliki pengaruh cukup signifikan terhadap produktivitas tanaman. Thomanee et al (1992) menyatakan bahwa penyakit gugur daun yang berkelanjutan dapat menurunkan produktivitas mencapai $40 \%$. Evaluasi klon terhadap sifat resistensi tanaman pada tingkat pengujian di lapangan, diharapkan dapat menghasilkan klon dengan ketahanan genetik yang lebih baik (Basuki, 1990).

Evaluasi klon terhadap ketahanan penyakit dilakukan di kebun Batang Toru, karena di kebun ini tergolong pada daerah basah. Klon karet yang diuji pada umumnya memiliki ketahanan tergolong agak resisten sampai dengan resisten terhadap penyakit gugur daun Oidium dengan intensitas serangan berkisar 9,82-26,90\% (Tabel 6). Terhadap penyakit Colletotrichum, seluruh klon yang diuji memiliki ketahanan yang tergolong moderat sampai dengan resisten dengan intensitas serangan berkisar 7,83$50,74 \%$. Ketahanan terhadap penyakit gugur daun Corynespora, klon IRR seri 100 yang diuji tergolong agak resisten sampai dengan resisten, dengan intensitas serangan berkisar $7,80-31,22 \%$.

\section{KESIMPULAN DAN SARAN}

Dari hasil evaluasi karakter pertumbuhan beberapa klon pada pengujian adaptasi diperoleh kesimpulan yaitu: klon IRR 104 dan IRR 118 memiliki pertumbuhan yang cukup jagur di daerah yang memiliki iklim kering, sedangkan klon IRR 5, IRR 112, PB 217 dan RRIM 921 memiliki pertumbuhan paling jagur di daerah yang memiliki iklim lebih basah. Klon IRR 5, PB 217, RRII 105, dan RRIM 921 memiliki karakter tebal kulit paling tinggi, sedangkan klon IRR 5, IRR 104, IRR 112, IRR 118, dan IRR 230 memiliki karakter anatomi kulit yang cukup baik. Semua klon yang diuji tergolong agak resisten hingga resisten terhadap penyakit gugur daun Oidium, Colletotrichum, dan Corynespora.

Untuk memperoleh informasi yang lebih lengkap tentang keunggulan klon-klon tersebut, maka pengamatan terhadap produktivitas pada masing-masing klon di daerah beriklim kering dan basah sedang dilakukan. Dengan bertambahnya informasi tersebut diharapkan terseleksi klon karet dengan pertumbuhan jagur dan produktivitas tinggi pada masing-masing wilayah pengujian.

Tabel 6. Intensitas serangan penyakit gugur daun dari beberapa klon karet Table 6. Attack intensity of leaf fall diseases of several rubber clones

\begin{tabular}{lcccccc}
\hline \multirow{2}{*}{ Klon } & \multicolumn{2}{c}{ Oidium } & \multicolumn{2}{c}{ Colletotrichum } & \multicolumn{2}{c}{ Corynespora } \\
\cline { 2 - 7 } & Intensitas & Ketahanan & Intensitas & Ketahanan & Intensitas & Ketahanan \\
& Intensity & Resistance & Intensity & Resistance & Intensity & Resistance \\
\hline IRR 5 & 20,98 & $\mathrm{AR}$ & 28,30 & $\mathrm{AR}$ & 10,86 & $\mathrm{R}$ \\
IRR 104 & 16,04 & $\mathrm{R}$ & 24,17 & $\mathrm{AR}$ & 31,22 & $\mathrm{AR}$ \\
IRR 112 & 10,10 & $\mathrm{R}$ & 12,67 & $\mathrm{R}$ & 3,25 & $\mathrm{R}$ \\
IRR 118 & 9,82 & $\mathrm{R}$ & 30,28 & $\mathrm{AR}$ & 31,14 & $\mathrm{AR}$ \\
IRR 119 & 24,66 & $\mathrm{AR}$ & 7,83 & $\mathrm{R}$ & 10,28 & $\mathrm{R}$ \\
IRR 230 & 12,11 & $\mathrm{R}$ & 9,00 & $\mathrm{R}$ & 19,50 & $\mathrm{R}$ \\
PB 217 & 22,72 & $\mathrm{AR}$ & 30,54 & $\mathrm{AR}$ & 7,80 & $\mathrm{R}$ \\
RRII 105 & 25,64 & $\mathrm{AR}$ & 23,78 & $\mathrm{AR}$ & 9,82 & $\mathrm{R}$ \\
RRIM 921 & 12,76 & $\mathrm{R}$ & 26,40 & $\mathrm{AR}$ & 10,87 & $\mathrm{R}$ \\
PB 260 & 10,62 & $\mathrm{R}$ & 28,21 & $\mathrm{AR}$ & 8,48 & $\mathrm{R}$ \\
\hline
\end{tabular}

Keterangan (Remarks) :

$\mathrm{AR}=$ agak resisten $($ moderately resistant) $\mathrm{R}=$ resisten (resistant) 


\section{DAFTAR PUSTAKA}

Aidi-Daslin, I. Suhendry and R. Azwar. 2000. Growth Characteristic and Yield Performance or Recommended Clones In Commercial Planting. Proceedings International Rubber Conference and IRRDB Symposium 2000. Bogor, 12-14 September. Indonesian Rubber Research Institute.: 150-158

Aidi-Daslin. 2005. Kemajuan Pemuliaan dan Seleksi Dalam Menghasilkan Kultivar Karet Unggul. Prosiding Lokakarya Nasional Pemuliaan Tanaman Karet 2005. Medan, 22-23 Nopember. Pusat Penelitian Karet.: 26-37.

Aidi-Daslin. 2011. Evaluasi Pengujian Lanjutan Klon Karet IRR Seri 200 Pada Masa Tanaman Belum Menghasilkan. Jurnal Penelitian Karet 29 (2): 93 - 101.

Alwi, N. dan Aidi Daslin. 1990. Laporan Mengenai Pengujian Klon Pertukaran Internasional 1974. Prosiding Lokakarya Nasional Pemuliaan Tanaman Karet 1990. Pontianak, 1417 Juli. Pusat Penelitian Karet.: 243249

Basuki, S. Pawirosoemardjo, U. Nasution, Sutardi, W.Sinulingga dan A. Situmorang. 1990. Penyakit Gugur Daun Colletotrichum Pada Tanaman Karet di Indonesia. Potensi, Penyebaran dan Penanggulangannya. Prosiding Lokakarya Nasional Pemuliaan Tanaman Karet 1990. Pontianak, 14-17 Juli. Pusat Penelitian Karet.: 268-295.

Chandrashekar, T. R., K. R. Vijayakumar, M. J. George and M. R. Sethuraj. 1994. Response of a Few Hevea Clones To Partial Irrigation During Immature Phase in a Dry Subhumid Climatic Region. J. Nat. Rubb. Res. 7 (2): $114-$ 119 .

Eberhart, S. A and W.A. Russell. 1966. Stability Parameters for Comparing Varieties. Crop Sci. 6: 36-40.

Fatunla, T and K. J. Frey. 1974. Stability Index and Non Radiated Oat Genotypes in Bulk Populations. Crop. Sci. 14: 719 -724 .
Goncalves, P. S., A. B. B. Cardinal., R. B. Dacosta., N. Bortoletto, and L. R. L. Gouvea. 2005. Genetic Variability and Selection for Laticiferous System Characters In Hevea brasiliensis. Genetic and Molecular Biology 28 (3) : 414-422.

Karyudi. 2001. Osmoregulasi Tanaman Karet Sebagai Respons Terhadap Cekaman Kekeringan. I. Variasi Diantara Klon Anjuran Harapan dan Plasmanutfah. Jurnal Penelitian Karet 19(1): $1-17$.

Mydin, K. K., T. Meenakumari., V. Thomas., T. Gireesh., C. Narayanan., T. R. Chandraseekar and J. Jacob. 2012. Multilocational Performance of RRII 400 Series Clones. Bulletin Rubber Board 30 (4) : $23-28$.

Novalina. 2009. Deteksi Marka Genetik yang Terpaut Dengan Komponen Produksi Lateks Pada Tanaman Karet (Hevea brasiliensis Muell Arg.) Melalui Pemetaan QTL. Disertasi. Program Pascasarjana. Institut Pertanian Bogor, Bogor.

Nor, K.M and F. B. Cady. 1979. Methodology for Identifying Wide Stability Analysis. Agron. J. 71: 556-559.

Pawirosoemardjo, S. 1999. Epidomologi dan Pengendalian Penyakit Gugur Daun Secara Terpadu. Laporan Penelitian. Proyek Penelitian Karet Sungei Putih. Medan.

Steel and Torrie. 1982. Principles and Procedures of Statistics. A Biometrical Approach. McGraw-Hill International Book Company. Tokyo.

Siagian, N, I. Suhendry dan H. Munthe. 2005. Keragaan Pertumbuhan Beberapa Klon Anjuran Pada System Tanam Populasi Tinggi dan Berbagai Dosis Pupuk. Prosiding Lokakarya Nasional Pemuliaan Tanaman Karet 2005. Medan 22-23 Nopember. Pusat Penelitian Karet.: 227-250

Simmond, N.W. 1989. Rubber Breeding. In: Webster C.C. and Baulkwill, W.J. (eds.). Rubber Longman Group, London. 
Suhendry, I., Aidi-Daslin, S. Woelan dan R. Azwar. 2001. Evaluasi Pendahuluan Genotipe Terpilih Penghasil LateksKayu. Prosiding Lokakarya Nasional Pemuliaan Karet 2001. Sembawa 5-6 Nopember. Pusat Penelitian Karet.: 201-214

Thomanee, A., S. Chimsathit, and S. Sookmark. 1992. Progress Report on the 1974 Multilateral Exchange Clone Trials. ANRPC Report of the First Meeting of Plant Breeders. Hat Yai, Thailand, $16^{\text {th }}-17^{\text {th }}$ Januari. The Association of Natural Rubber Producing Countries.: 48-60
Woelan, S., Aidi-Daslin, R. Azwar, dan I. Suhendry. 2001. Keragaan Klon Karet Unggul Harapan Seri 100. Prosiding Lokakarya Nasional Pemuliaan Karet 2001. Sembawa, 5-6 Nopember. Pusat Penelitian Karet.: 173-187

Wijaya, T., A. Gunawan, H. Suryaningtyas, dan G. Wibawa. 2001. Dampak dan Penanggulangan Kekeringan Pada Usaha Perkebunan Karet Dalam Amypalupy dan T. Wijaya. 2009. Ketahanan Beberapa Klon Karet Anjuran terhadap Kekeringan. Jurnal Penelitian Karet 27 (1): 32-41 